\title{
A PROFILE OF HUMAN IMMUNODEFFICIENCY VIRUS INFECTED PATIENTS IN YENEPOYA MEDICAL COLLEGE HOSPITAL WITH SPECIAL REFERANCE TO CORRELATION BETWEEN CD4 COUNT AND TOTAL LYMPHOCYTE COUNT
}

Sajid Chalihadan ${ }^{1}$, Mohammed Kunhi², C.P. Abdul Rahman ${ }^{3}$

\section{HOW TO CITE THIS ARTICLE:}

Sajid Chalihadan, Mohammed Kunhi, C.P. Abdul Rahman."A Profile of Human Immunodeficiency Virus infected patients in Yenepoya Medical College Hospital with special reference to Correlation between CD4 Count and total Lymphocyte Count". Journal of Evolution of Medical and Dental Sciences 2013; Vol. 2, Issue 52, December 30; Page: 10204-10227.

ABSTRACT: BACKGROUND AND OBJECTIVES:To study the clinical presentation, spectrum of systemic involvement, opportunistic infections and the correlation between CD4 + cell count and TLC for monitoring disease progression in HIV patients. Previous studies have shown that TLC is an inexpensive and useful tool for monitoring HIV progression.METHODS: This was a 2 year prospective study in which cases were examined and according to theproforma, TLC and CD4+ counts were assessed in 50 HIV positive patients who attended Yenepoya Medical College Hospital, Mangalore between October 2005 and September 2007. Sensitivity and specificity of various TLC cut-off were computed for CD4 count $<200$ cells/mm3 and statistical indices computed. Pearson's correlation coefficient was used to find out the correlation between CD4+ count and TLC at baseline.RESULTS: 45 male and 5 female patients, having mean age of 38.08 9.01 years (range 20 60 years) were studied. $70 \%$ were in $20-40$ years age group. $34 \%$ were related to transport services. Heterosexual mode of transmission was seen in $64 \%$, commonest presenting symptoms were fever and weight loss, oral candidiasis was present in $26 \%$ and lymphadenopathy in $46 \%$ of subjects. Tuberculosis was the most common opportunistic infection seen in $68 \%$ of subjects. One patient had AIDS dementia complex, one had HIV nephropathy and in 1 and a presumptive diagnosis of Kaposi's sarcoma was made. Tubercular meningitis was the most common neurological manifestation. The mean baseline CD4+ count in study group was 175 cells $/ \mathrm{mm} 3$. The mean baseline TLC was 1338 cells/mm3. The scatter diagram shows, as the CD4 $\mathrm{T}$ cells rises, the TLC level also rises. The sensitivity and specificity of TLC $<1200$ and CD 4 count $<200$ was $91 \%$ and $53 \%$ respectively with a positive predictive value of $70 \%(\mathrm{p}=0.0001)$.CONCLUSION: Occupation was the important risk factor for HIV transmission and heterosexual contact is the commonest mode of spread. Among opportunistic infections, tuberculosis was most common. There was a definite correlation between the TLC and CD4 count in HIV positive patients before treatment. It is evident from this study that TLC can be used in place of CD4+ T cell counts in resource-limited settings to monitor the disease progression.

INTRODUCTION: The world wide epidemic of Human Immunodeficiency Virus (HIV) is an international health problem of extraordinary scope and unprecedented urgency ${ }^{1}$.Since 1980 till today HIV epidemic has continued its dramatic expansion universally, both geographically and in terms of risk groups. The epidemiological scenario is also changing, from a disease mainly ofhomosexual males to a rapidly growing population of HIV infected females, children and men who 


\section{ORIGINAL ARTICLE}

are not homosexuals. The spectrum of HIV infection includes asymptomatic cases to AIDS at other extreme. The diagnosis rests on clinical manifestations and laboratory markers.

In India, the socioeconomic and cultural environment is important in disease transmission and prevalence, as also the clinical spectrum is very different from western society. One of the purposes of this study was to know the different patterns of clinical presentation of HIV infection in this region

Soon after HIV was foundto be the cause of AIDS, it was shown that the virus binds to receptors on CD4 cells, enters the cells, and uses them to create new virus, destroying them in the process. This results in the depletion of CD4 cells and immunodeficiency. ${ }^{2}$

With the increased availability of equipment to perform CD4 counts and the knowledge that CD4 cells were the primary target of HIV, the determination of CD4 count became the standard measure of immunodeficiency in adult HIV-infected patients in resource-rich countries. The relative ease of CD4 cell monitoring also led to its advocacy in treatment guidelines for determining when to start, stop, or change ART and for deciding when to initiate prophylaxis for opportunistic infections (OIs). This is despite the fact that CD4 count does not always correlate with functional immunity; some patients with normal CD4 counts are susceptible to OIs and some patients with significantly depressed CD4 counts do not seem unduly susceptible to OIs.

The determination of CD4 cell count and percentage is too expensive for most health facilities in resource-poor countries like India to perform routinely ${ }^{3}$. In contrast, TLC can be derived easily in resource-poor countries by performing a routine white blood cell count.TLC is the total white blood cell count multiplied by the lymphocyte percentage; for example, a total white blood cell count of 6,000 cells / $\mu \mathrm{L}$ with a lymphocyte percentage of $30 \%$ would result in a TLC of 1, 800 cells / $\mu \mathrm{L}^{3}$. The equipment and skills to perform total white blood cell count and differential are readily available in most hospitals and clinics in resource-poor countries. The need to rapidly expand the use of ART in resource-poor countries as well as the human resource constraints, cost, and infrastructure concerns surrounding CD4 cell measurements have prompted to evaluate the utility and predictability of TLC as a measure of immune function and its usefulness in guiding initiation of ART. This study also attempts to correlate CD4 count with TLC

\section{MATERIALS AND METHODS}

Design: Prospective study of 2yrs from October 2005 to October 2007.

Setting: YenepoyaMedical College\&Hospital

1. Inclusion Criteria: AdultHIVpositivepatientsabove16yrswithadefinitediagnosisofHIVIllness byCDCrevisedsurveillance.

\section{Exclusion Criteria}

1. Pediatric HIV positive patients.

2. Patients on immunosuppressant therapy.

3. Patients who are diagnosed as HIV positive earlier and on treatment for the same.

Patient Enrollment and Monitoring: 50 cases of HIV positive patients were recruited from all treating units at YenepoyaMedicalCollege Hospitalfrom October 2005 to October 2007.

These patients were also treated for opportunistic infections.

Method of collection of Data: Diagnosis of HIVwasmade in these patients by

Detailed clinical history and physical examination. 


\section{ORIGINAL ARTICLE}

Routine laboratory investigations including Elisa(2 ELISA).

Venous samples were sent for evaluation of CD4 count (by Flow cytometric method). At the same time samples were sent for evaluation ofTLC.

Total lymphocyte count (TLC) was calculated by multiplying the differential lymphocyte count with the total leucocyte count. [TLC=Total leucocyte countx Differential lymphocyte count]

In the patients who were symptomatic, the following investigations were done.

Collection and processing of specimens: Various samples e.g. sputum, oral swab, blood, stool, urine, cerebrospinal fluids (CSF), lymph node aspirate were collected as per symptoms and clinical presentations. All the specimens were collected under universal aseptic precautions in suitable sterile containers.

Oralswab: Oral swabs were collected in cases presenting with oral thrush. Two sterile swabs were taken and each rubbed against the right tonsil and rolled along the soft palate to the left tonsil. Curdy white patches were also swabbed. Gram staining was done with one swab and the other swab was streaked on sabourauds dextrose agar slope. Germ tube test was also performed for presumptive identification of Candida albicans

Stool: Fresh samples of stool were collected in sterile, dry, leak proof, wide-mouthed container.

Wet mount- Direct saline mounts and iodine mounts were screened under microscope for helminthes eggs, larvae, protozoan cysts, trophozoites, pus cells and possible fungal elements. After concentration method supernatants were discarded, sediment was used for Kinyoun cold test for detection of oocysts of cryptosporidium, cyclospora, isospora and sarcocystis.

Sputum: Early morning sputum was collected in a wide mouthed sterile container. Instructions were given to rinse the mouth with tap water before sample collection, and to collect expectoration and not saliva.

Wet mount- sputum sample was taken on a clean glass slide and 2 drops of $10 \% \mathrm{KOH}$ was added and covered with a cover slip. Slip was kept in incubator at 37 degree c for 10 mins and examined for fungal elements.

Staining of sputum was done for detection of

- Gram stain- to see pyogenic bacteria, pus cells and epithelial cells

- Ziehl- Neelsen stain for acid fast bacilli

- Methanamine silver nitrate stain- for the detection ofpneumocystis carini cysts

Urine: Mid-stream urine samples were collected in sterile container. All the samples were processed within one hour of collection. Gram stain was done to detect pus cells, epithelial cells, bacteria and yeast cells.

Cerebrospinal fluid (CSF): CSF samples were obtained by lumbar puncture and processed immediately. CSF fluid was sent to microbiology for

- Culture

- Staining- gram stain, Ziehl-Neelsen's stain and methylene blue stains were used to detect different pathogens

- India ink wet mount- it was done to detect presence of Cryptococcus.

Blood: Skin at the site of venipuncture was cleaned with $70 \%$ alcohol followed by $2 \%$ tincture iodine. Total $15 \mathrm{ml}$ blood was collected from each patient. $10 \mathrm{ml}$ was used for blood culture and $5 \mathrm{~m} 1$ was collected in sterile penicillin vial for serological tests. 
Serology: The blood collected in penicillin vial was allowed to clot. Samples were centrifuged and serum was collected for following tests

- VDRL

- $\quad \mathrm{HbsAg}$

- $\mathrm{HCV}$

Method of Statistical Analysis: Sensitivity and specificity of various total lymphocyte count cut offs were computed for CD4 count $<200$ cells $/ \mathrm{mm} 3$. Correlated and statistical indices computed for all patients.

Sensitivity, Specificity, Positive Predictive value and Negative Predictive value:TLC values at 1200 or less, compared with CD 4 values at $<200$, then the number of patients with True Positive (TP), False Positive (FP), True Negative (TN) and False Negative (FN)were determined. The following were calculated:

Sensitivity: [TP/ (TP+FN)]

Specificity: [TN/ (TN+FN)]

Positive Predictive Value: $\mathrm{PPV}=[\mathrm{TP} /(\mathrm{TP}+\mathrm{FN})]$

Negative Predictive Value: NPV $=[\mathrm{TN} /(\mathrm{FN}+\mathrm{TN})$

In the above test $\mathrm{P}$ value less than 0.05 were taken to be statistically significant. The data was analyzedusing Statistical Package for Social Science (SPSS) package.

RESULTS AND ANALYSIS: A total number of 50 cases of HIV infected patients admitted in YenepoyaMedicalCollegeHospital, Mangalore who met the inclusion criteria were studied.

\section{AGE AND SEX DISTRIBUTION:}

\begin{tabular}{|c|c|c|c|}
\hline Age in years & Male & Female & Total \\
\hline$<20$ & - & - & - \\
\hline $21-30$ & 12 & 1 & 13 \\
\hline $31-40$ & 20 & 2 & 22 \\
\hline $41-50$ & 10 & 2 & 12 \\
\hline $51-60$ & 2 & - & 2 \\
\hline$>61$ & 1 & - & 1 \\
\hline
\end{tabular}

Table No. 1: The age and sex distribution

Out of the 50 cases studied, $45(90 \%)$ were males and the remainder $5(10 \%)$ were females. Their ages ranged from 20 years to 60 years with a mean of $38.08 \pm 9.01$. The ratio ofMale: Female was 9: 1 . The maximum incidence of $70 \%$ was seen in the age group between 20 to 40 years, of which $91.42 \%(32 / 35)$ were males. (Table. 1, Fig 1) 


\section{ORIGINAL ARTICLE}

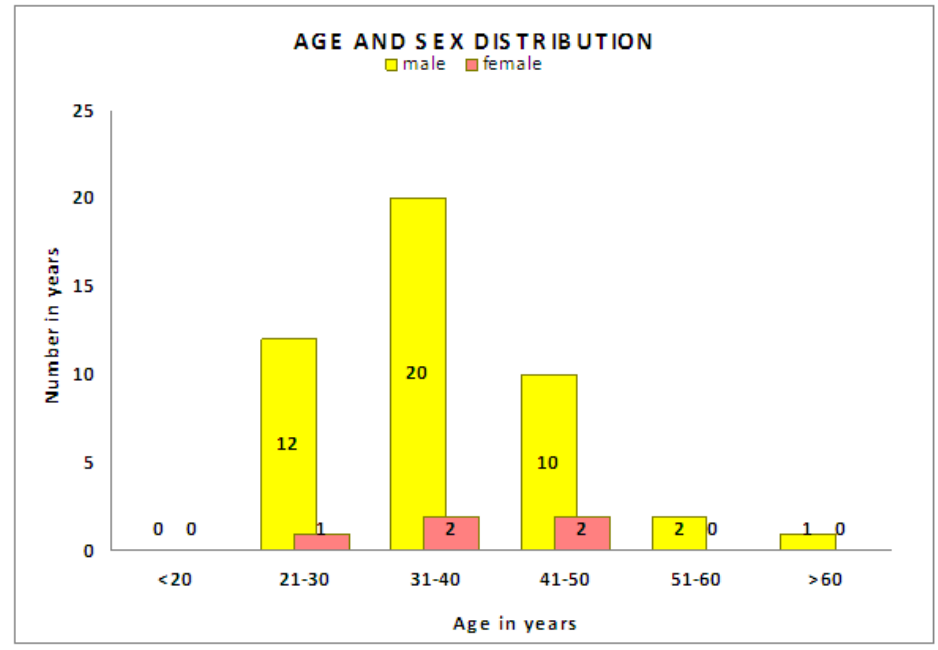

FIGURE No: 1

\section{OCCUPATION:}

\begin{tabular}{|c|c|c|c|}
\hline & Male & Female & Total \\
\hline Transport & 17 & - & 17 \\
\hline Farmers & 5 & - & 5 \\
\hline Hotel workers & 11 & - & - \\
\hline Laborers & 7 & 1 & 8 \\
\hline Others & 5 & 4 & 9 \\
\hline
\end{tabular}

\section{Table No. 2: Sex wise distribution of different types of occupations}

Out of the 50 cases studied, 34\% (17/50) were in transport, $22 \%(11 / 50)$ were hotel workers, $16 \%(8 / 50)$ were laborers, and the rest constituted farmers, businessmen, housewives. (Table.2, Fig 2)

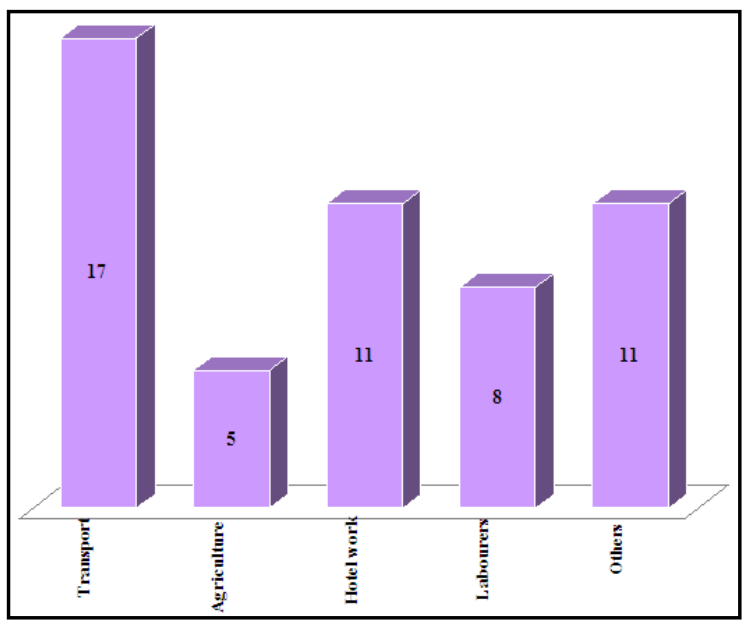

Fig. 2: Distribution of types of occupation 


\section{ORIGINAL ARTICLE}

\section{MODE OF TRANSMISSION:}

Out of 50 cases, 64\% (32/50) had heterosexual (multiple sexual partners), Homosexual 10\% (5/50), Blood transfusion $0.5 \%(1 / 50)$ andmode of transmission and history could not be obtained in $24 \%$ (12/50). (Fig 3).

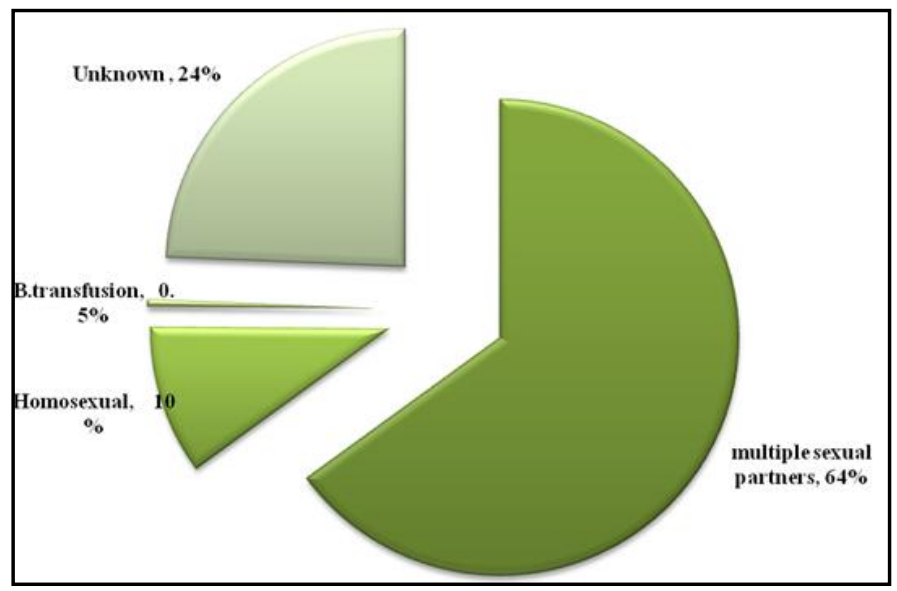

Fig. 3: Distribution of Mode of Transmission

4. DURATION SINCE TIME OF FIRST RISK EXPOSURE:Duration since time of first risk exposure ranged from 2 years to 20 years with themean of $8.27 \pm 4.181$.

\section{PRESENTING SYMPTOMS}

\begin{tabular}{|l|c|c|c|}
\hline Presenting symptoms & Male & Female & Total \\
\hline Fever > 1 month & 36 & 4 & 40 \\
\hline Cough & 27 & 2 & 29 \\
\hline Diarrhea > 1 month & 9 & 2 & 11 \\
\hline Significant weight loss & 39 & 3 & 42 \\
\hline Abdominal pain & 10 & - & 10 \\
\hline Headache & 5 & 1 & 6 \\
\hline Seizures & 3 & - & 3 \\
\hline Altered sensorium & 2 & 0 & 2 \\
\hline Dysphagia & 1 & 1 & 2 \\
\hline Ear discharge. & 1 & - & 1 \\
\hline \multicolumn{2}{|c|}{ Table No. 3: Sex wise distribution } \\
\hline \multicolumn{2}{|c|}{ of presenting symptoms } \\
\hline
\end{tabular}

Out of 50 cases, most common presenting symptoms were fever of more than 1 month in $80 \%(40 / 50)$ and significant weight loss in 84\% (42/50), 58\% (29/50) had cough out of which 40\% (20/50) had expectoration. 22\% (11/50) had diarrhea of more than 1 month. Pain in abdomen was complained by $20 \%(10 / 50)$ of patients, $12 \%$ (6/50) hadheadacheand6\% (3/50) had seizures of generalized tonic clonic type. Two patients presented with altered sensorium and two with dysphagia. Purulent discharge from the ear was complained by one patient. (Table.3, Fig 4). 


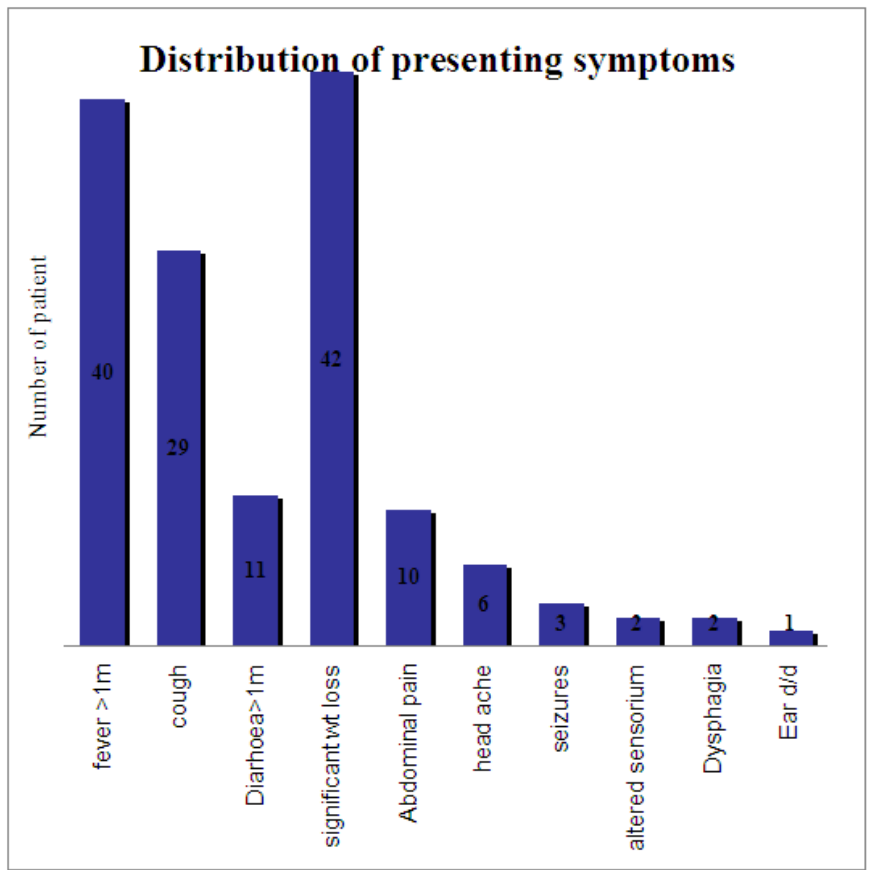

\section{Fig. 4}

\section{CLINICAL SIGNS}

\begin{tabular}{|l|c|c|c|}
\hline \multicolumn{1}{|c|}{ Signs } & Male & Female & Total \\
\hline Lymphadenopathy & 17 & 3 & 20 \\
\hline Oral candidiasis & 10 & 3 & 13 \\
\hline Skin lesions & 7 & 0 & 7 \\
\hline
\end{tabular}

Table No. 4: Sex wise distribution of clinical signs

Of the total number of patients studied on general physical examination, $40 \%(20 / 50)$ had palpable lymphnodes, 26\% (13/50) had oral candidiasis, 14\% (7/50) had skin manifestations and commonest manifestation was papular eruption seen in $42.85 \%$ (3/7) of cases, seborrheic dermatitis, hypopigmented macules, penile ulcer were seen in 57.16\% (4/7) cases. (Table 4, Fig 5).

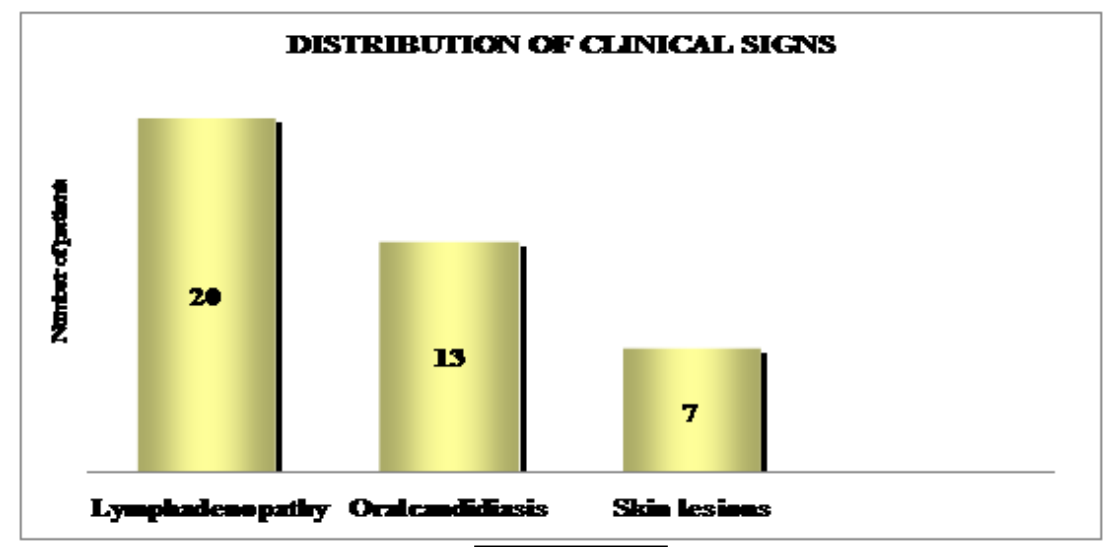

\section{Fig. 5}


7.LABORATORY PROFILE:Hemoglobinestimation was done in 50 cases. 14\% (7/50) had hemoglobin of less than $8 \mathrm{gm} \%$ and $26 \%$ (13/50) had hemoglobin of more than $12 \mathrm{gm} \%$ with mean of $10.42 \pm 1.99$. Peripheralsmear in $62 \%$ ofcaseswerenormocytic normochromic type. (Table 5, Fig $6)$.

\begin{tabular}{|c|c|c|c|}
\hline Hemoglobin in gm.\% & Male & Female & Total \\
\hline$<8$ & 4 & 3 & 7 \\
\hline $8-10$ & 16 & 1 & 17 \\
\hline $10-12$ & 12 & 1 & 13 \\
\hline$>12$ & 13 & - & 13 \\
\hline \multicolumn{2}{|c|}{$\begin{array}{c}\text { Table No. 5: Sex wise Distribution } \\
\text { of Hemoglobin Levels }\end{array}$} \\
\hline
\end{tabular}

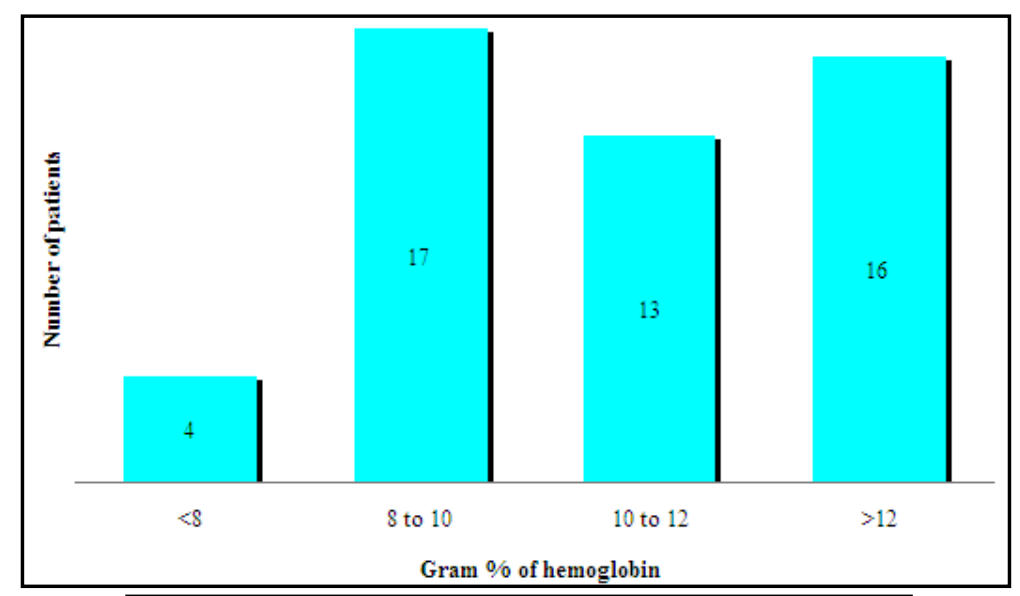

Fig. 6: Distribution of Himoglobin levels

\begin{tabular}{|l|c|c|c|}
\hline \multicolumn{1}{|c|}{ Peripheral smear } & Male & Female & Total \\
\hline Microcytic hypochromic & 14 & 2 & 16 \\
\hline NormocyticNormochromic & 28 & 3 & 31 \\
\hline Normocytic hypochromic & 0 & 0 & 0 \\
\hline Dimorphic & 2 & 0 & 2 \\
\hline Thrombocytopenia & I & 0 & 1 \\
\hline
\end{tabular}

Table No. 6: Sex wise distribution of peripheral smear study

TLCvs.CD4+COUNT: The overall mean baseline CD4+ counts in study group was 175 cells/mm3 while the overall mean baseline Total Lymphocyte count (TLC) in study groupwas 1338 cells/mm3.There is a fair positive correlation between CD4 count and TLC ( $\mathrm{r}=0.55, \mathrm{p}=<0.0001)$. (Table 7, Fig 7)

\begin{tabular}{|c|c|}
\hline & TLC \\
\hline \multirow{2}{*}{ CD4 } & r: 0.55 \\
& p: $<0.0001$ \\
\hline
\end{tabular}

Table No. 7: Pearson Partial Correlation Coefficient 


\section{ORIGINAL ARTICLE}

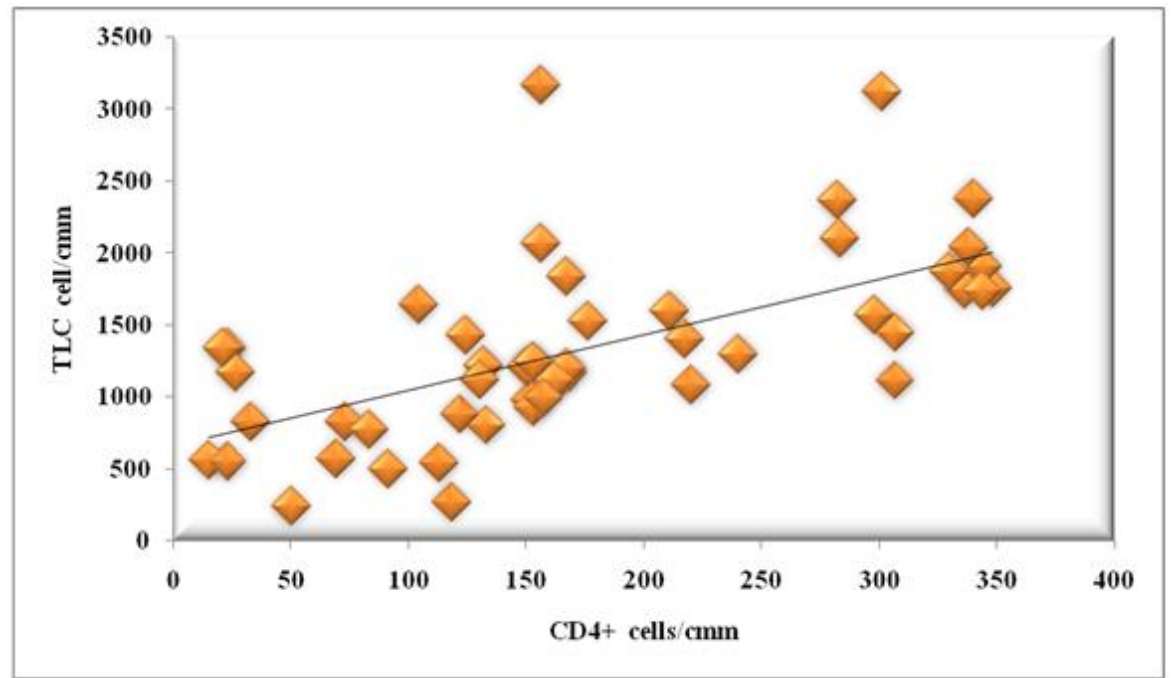

Fig. 7: Scatter plot of CD4+ counts vs TLC

\begin{tabular}{|c|c|c|c|c|c|}
\hline \multicolumn{3}{|c|}{ TLC } & $<\mathbf{1 2 0 0}$ & $>\mathbf{1 2 0 0}$ & Total \\
\hline \multirow{4}{*}{ CD4 } & $<200$ & $\begin{array}{r}\text { No } \\
\mathbf{\%}\end{array}$ & $\begin{array}{c}20 \\
60.61 \%\end{array}$ & $\begin{array}{c}13 \\
39.39 \%\end{array}$ & 33 \\
\cline { 2 - 6 } & $>200$ & $\begin{array}{r}\text { No } \\
\mathbf{\%}\end{array}$ & $\begin{array}{c}2 \\
11.76 \%\end{array}$ & $\begin{array}{c}15 \\
88.24 \%\end{array}$ & 17 \\
\hline \multicolumn{2}{|c|}{ Total } & No. & 22 & 28 & 50 \\
\hline
\end{tabular}

Table No. 8: CD4+ Count $<200$ vs. TLC $<1200$

When patients with CD4 count of $<200$ cells/mm3 and TLC of $<1200$ cells/mm3 were correlated, the results showed a highly significant statistical correlation( $\mathrm{P}<0.001)$ with sensitivity of $91 \%$ and specificity of $53 \%$ and positive predictive value of $70 \%$ and negative predictive value of $30 \%$.

\section{CHESTX - RAY:}

\begin{tabular}{|l|c|c|c|}
\hline \multicolumn{1}{|c|}{ Type of lesion } & Male \% & Female \% & Total \% \\
\hline Upper zone lesions & 17.8 & 0 & 17.8 \\
\hline B/L infiltrations & 39.28 & 7.14 & 46.42 \\
\hline Lower zone lesion & 10.71 & 0 & 10.71 \\
\hline Pleural effusion & 7.1 & 3.61 & 10.71 \\
\hline Pneumothorax & 3.57 & 0 & 3.57 \\
\hline Cardiomegaly & 3.57 & 0 & 3.57 \\
\hline Miliary mottling & 7.14 & 0 & 7.14 \\
\hline
\end{tabular}

Table No. 9: Sex wise distribution of various chest X-ray patterns

Out of 50 patients studied, 28 had radiological abnormalities. There were apical lesions in 5 , bilateral extensive infiltrations in 13, cardiomegaly in 1, pleural effusion in 3, lower lobe opacities in 3, pneumothoraxin1andmiliarymottlingin2. (Table 9, Fig 8)) 


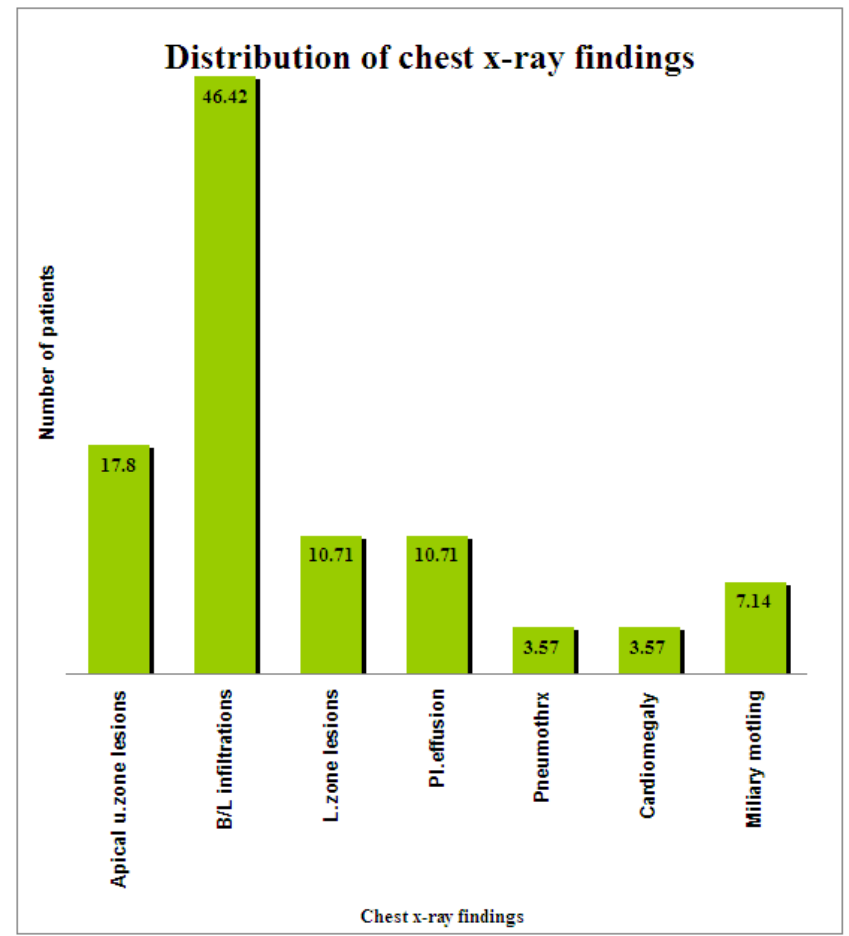

Fig. 8

Opportunisticinfections and other associated conditions in HIV infected patients

Tuberculosis: Out of 50 cases studied, tuberculosis was the commonest opportunistic infection with $68 \%$ (34/50) of cases having tuberculosis. 38.23\% (13/34) had only pulmonary tuberculosis, $38.23 \%(13 / 34)$ had only extra pulmonary tuberculosis and $23.53 \%(8 / 34)$ had both pulmonary and extra pulmonary tuberculosis. (Fig 9).

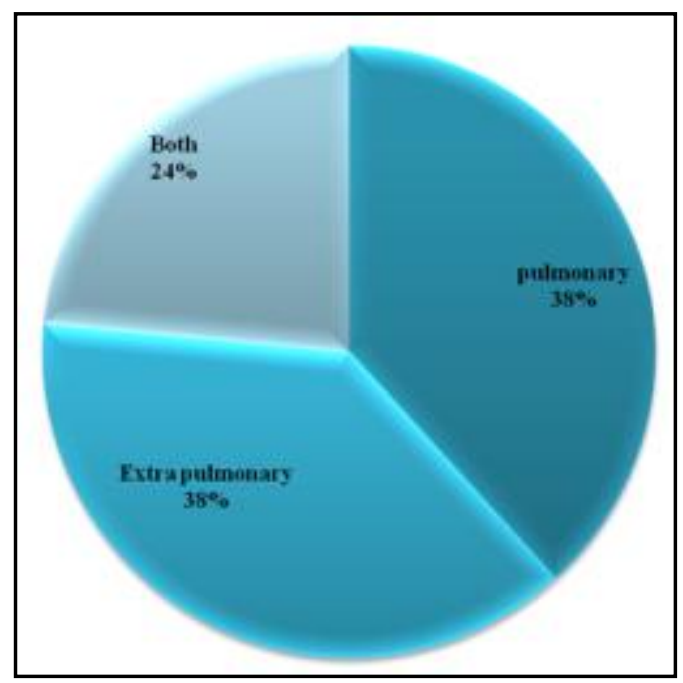

\section{Fig. 9: Distribution of types of Tuberculosis}




\section{ORIGINAL ARTICLE}

Secondary Infections:Out of 50 cases, 6\% (3/50) had secondary bacterial non opportunistic infections, out of which 2 were pneumonia caused by gram negative bacilli and 1 was of chronic suppurative otitis media.

Neurological manifestations:Out of 50 cases, 28\% (14/50) had neurological manifestations. Out of them 50\% (7/14) had tubercular meningitis, 14.28\% (2/14) had tuberculoma, 14.28\% (2/14) had tubercular arachnoiditis presenting with myeloradiculopathy. 1 patient was diagnosed to have HIV encephalopathy (AIDS dementia complex) and 2 patients had progressive multifocal leukoencephalopathy.(Fig 10).

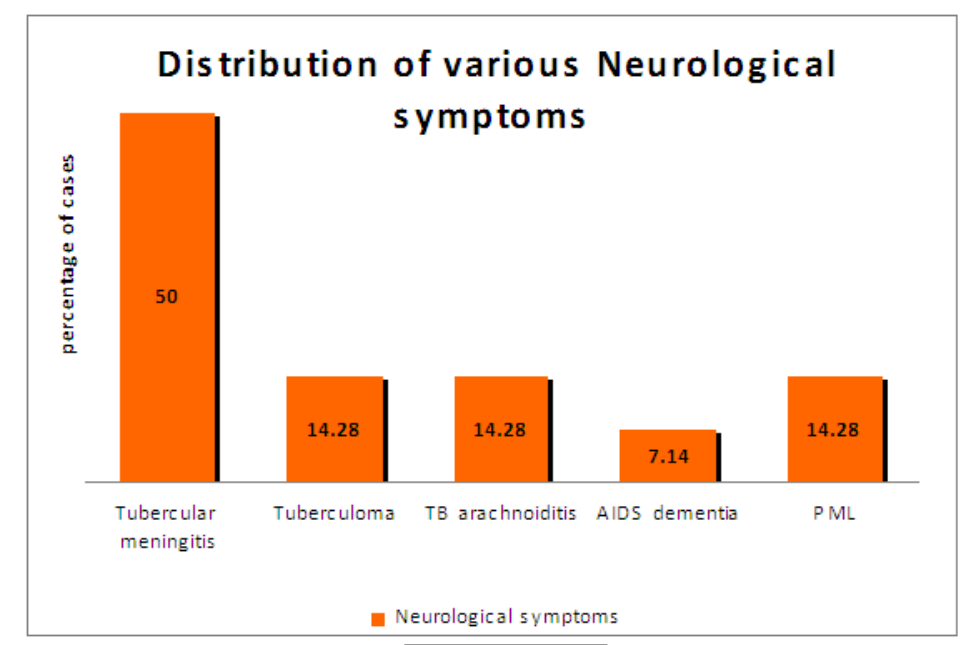

\section{Fig. 10}

Sexually transmitted diseases:One patient i.e. $2 \%(1 / 50)$ had gonorrhea and one patient was diagnosed tohave hepatitis B.

Persistent generalized lymphadenopathywas found in one out of 50cases studied.

Renal manifestation:Out of 50 cases studied, one patient had HIV associated nephropathy and one patient had chronic renal failure.

Malignancy:Out of 50 cases studied, one patient had Non-Hodgkin's lymphoma and in one patient probable diagnosis of Kaposi's sarcoma was made.

Fever of Unknown Origin:Out of 50 patients, 80\% (40/50) had fever of more than 1 month duration, of which definitive diagnosis could not be made in 3 cases and were diagnosed as fever of unknown origin.

\begin{tabular}{|l|c|}
\hline \multicolumn{1}{|c|}{ Parameter } & Percentage of cases \\
\hline Tuberculosis & 68 \\
\hline Pulmonary & 20 \\
\hline Extra-pulmonary & 38 \\
\hline Both & 10 \\
\hline Secondary bacterial infections & 6 \\
\hline Neurological symptoms & 28 \\
\hline
\end{tabular}


ORIGINAL ARTICLE

\begin{tabular}{|l|c|}
\hline Tubercular meningitis & 50 \\
\hline Tuberculoma & 14.28 \\
\hline TB arachnoiditis & 14.28 \\
\hline AIDS dementia & 7.14 \\
\hline $\begin{array}{l}\text { Progressive multifocal } \\
\text { leucoencephalopathy }\end{array}$ & 14.28 \\
\hline Sexually transmitted diseases & 4 \\
\hline Gonorrhea & 2 \\
\hline Hepatitis B & 2 \\
\hline Renal Manifestations & 4 \\
\hline HIV associated nephropathy & 2 \\
\hline Chronic renal failure & 2 \\
\hline Fever of unknown origin & 6 \\
\hline Malignancy & 4 \\
\hline Non-Hodgkin's lymphoma & 2 \\
\hline ?Kaposi's Sarcoma & 2 \\
\hline $\begin{array}{l}\text { Persistent generalized } \\
\text { Lymphadenopathy }\end{array}$ & 2 \\
\hline $\begin{array}{l}\text { Table No. 10: Distribution of various opportunistic } \\
\text { Infections and other manifestations. }\end{array}$ \\
\hline
\end{tabular}

DISCUSSION: The observations made in 50 cases of HIV infected patients admitted to YenepoyaMedicalCollegeHospital, Mangalore between October 2005 to September 2007, are discussed and compared with other studies.

1. AGE AND SEX:G hate M.V et a $1^{4}$ in his study on changing trends in clinical presentation of HIV infected persons in Pune found that $88.1 \%$ of the cases were in the agegroup between 21 years and 40 years and it was the male population that was more affected ascompared to the females with male to female ratio of 2.22:1.

Study done by Kothari K et $\mathrm{a}^{5}$ in 2001 showed that $90 \%$ of the cases were in the age group of 20 to 40 years and male population constituted $83.33 \%$ with male to female ratio of 5: 1 . In a study done by Mandal A.K et a $16,81.16 \%$ of cases were in the age group of 20 to 40 years with male to female ratio of $1.5: 1$.

The age of the patients in the present study ranged from 20 to 61 years with $90 \%$ males and $10 \%$ females with a male to female ratio of 9:1.

The incidence of maximum number of HIV infected cases in the age group of 20 to 40 is comparable with other studies.

This finding of male preponderance is comparable with other studies that the incidence of HIV infection is more common in males than females. This data suggests that sexually active population is more affected. 
The comparable studies are shown in a tabular column below

\begin{tabular}{|c|c|c|c|c|c|}
\hline Study series & $\begin{array}{c}\text { Total } \\
\text { number of } \\
\text { patients }\end{array}$ & $\begin{array}{c}\text { Males } \\
\text { in \% }\end{array}$ & $\begin{array}{c}\text { Females } \\
\text { in \% }\end{array}$ & M:F & $\begin{array}{c}\mathbf{2 1 - 4 0} \\
\text { years in\% }\end{array}$ \\
\hline $\begin{array}{c}\text { Mandal A.K } \text { etal }_{(2000)} \\
(2001)\end{array}$ & 88 & 60.87 & 39.13 & $1.5: 1$ & 81.16 \\
\hline $\begin{array}{c}\text { Kothari } \mathrm{K}^{5} \text { et al } \\
(2002)\end{array}$ & 2801 & 68.97 & 31.02 & $2.22: 1$ & 88.1 \\
\hline $\begin{array}{c}\text { Ghate M.V4 } \mathrm{V}^{4} \text { et al } \\
(2002)\end{array}$ & 50 & 90 & 10 & $9: 1$ & 70 \\
\hline Present study & & & 16.66 & 50 \\
\hline
\end{tabular}

2. Occupation: Mandal A.K $\mathrm{K}^{6} \mathrm{et}$ al in his study found that the main risk groups were truck drivers and laborers. Study done by Kothari $\mathrm{K}$ et $\mathrm{al}^{5}$ showed that major risk group was people in transport services constituting $40 \%$ of all cases.

In the present study people in transport services constituted $34 \%$ of all cases and Hotel workers constituted $22 \%$ of all cases.

This finding is comparable with other studies that the incidence of HIV infection was high among people working in transport probably because of longer duration of stay away from the family.

\begin{tabular}{|l|c|c|c|}
\hline Occupation & $\begin{array}{c}\text { Mandal AK et al } \\
\text { al (2000 in \%) }\end{array}$ & $\begin{array}{c}\text { Kothari k et al5 } \\
\text { al (2001 in \%) }\end{array}$ & $\begin{array}{c}\text { Present Study } \\
\text { ( \% ) }\end{array}$ \\
\hline Transport & 11.36 & 40 & 34 \\
\hline Laborer & 17.05 & 20 & 16 \\
\hline Farmers & - & 16.67 & 10 \\
\hline Hotel worker & - & - & 22 \\
\hline $\begin{array}{l}\text { Female sex } \\
\text { worker }\end{array}$ & 10.22 & - & - \\
\hline Others & 61.36 & 23.33 & 18 \\
\hline
\end{tabular}

4. Mode of transmission:John T.J et $\mathrm{al}^{7}$ in his study showed that $90 \%$ of the patients had multiple sex partners and heterosexual route was the major mode of transmission.

Rajasekaran Set $\mathrm{al}^{8}$ showed heterosexual promiscuity in $74.4 \%$ of patients. Of the remaining, $15.38 \%$ were females who had acquired the infection through their HIV infected husbands while remaining $10.25 \%$ constituted commercial sex workers and intravenous drug abusers.

Kothari Ket al $^{5}$ in his study showed that heterosexuality accounted for $90 \%$ of the total cases.

In this study, heterosexual mode of transmission was the major mode of transmission in $64 \% ; 10 \%$ showed homosexual and in the remaining $24 \%$ of the cases reliable history could not be elicited. 


\section{ORIGINAL ARTICLE}

This finding isnot comparable with other studies.

4. Presenting symptoms: A study of common presenting symptoms and signs was made. We noted that fever and weight loss were themost common presenting symptoms constituting $80 \%$ and $84 \%$ of cases respectively. This finding is comparable with other studies done by Colebunders $\mathrm{R}$ et $\mathrm{al}^{9}$, showed fever and weight loss in $21.83 \%$ and $29.31 \%$, Lakshmi V. et al 10 in $61 \%$ and $45 \%$, Kothari $\mathrm{K}$ et $\mathrm{al}^{5}$ in $96 \%$ and $66 \%$ of cases. Then next common symptom in our study was cough $>1$ month in $58 \%$ of cases which was comparable with study done by Kothari $\mathrm{K}$ et $\mathrm{al}^{5}$ who showed cough $>1$ month in $60 \%$ of cases. However in studies done by Colebunders $\mathrm{R}$ et $\mathrm{al}^{9}$ and Lakshmi $\mathrm{V}$ et al ${ }^{10}$, only $15.5 \%$ and $11 \%$ of cases had cough respectively.

We see that present study has reported a higher incidence of cough $>1$ month as compared to the two above mentioned studies. This could be explained by higher incidence of tuberculosis in the present study.

Next common symptom reported in the present study was diarrhea $>1$ month, in $22 \%$ of cases. This finding is comparable with studies done by Lakshmi V et al ${ }^{10}$ and Kothari Ket $\mathrm{al}^{5}$ which showed an incidence of $23 \%$ in both the studies.

However in a study done by Colebunders $\mathrm{R}$ the above mentioned symptom was seen in only $9.77 \%$ of cases, which is lower incidence compared to the present study.

Pain abdomen was seen in $20 \%$ of cases in the present study. HoweverLakshmiv et al ${ }^{10}$ reported in $9 \%$ of cases and Kothari $\mathrm{K}$ et al 5 in $6.6 \%$ of cases.

This study showed a higher incidence of this symptom compared to the above mentioned studies.

Altered sensorium was seen in $4 \%$ of cases in present study. Kothari Ket al ${ }^{5}$ reported the same in $26 \%$ of cases. The present study hadrecorded a lower incidence as compared to the study done by Kothari $\mathrm{K}$ et al, probably due to the small study population in our study when compared to the other.

Dysphagia was seen in $4 \%$ of cases in the present study. However Kothari $\mathrm{K}$ et $\mathrm{al}^{5} \mathrm{reported}$ $30 \%$ of cases.

The table showing the comparable studies is given below

\begin{tabular}{|l|c|c|c|c|}
\hline & $\begin{array}{c}\text { Colebunder R } \\
\text { et al }^{\mathbf{9}} \mathbf{( 1 9 8 7 )} \\
\mathbf{\%}\end{array}$ & $\begin{array}{c}\text { Lakshmi V } \\
\text { et al10 } \\
\mathbf{( 1 9 9 8 )} \\
\mathbf{\%}\end{array}$ & $\begin{array}{c}\text { Kothari } \\
\text { K et al }^{\mathbf{5}} \\
\mathbf{( 2 0 0 1 )}\end{array}$ & $\begin{array}{c}\text { Present } \\
\text { Study } \\
\mathbf{\%}\end{array}$ \\
\hline Fever >lmonth & 21.83 & 61 & 96 & 80 \\
\hline Weight loss >10\% & 29.31 & 45 & 66 & 84 \\
\hline Cough > 1 month & 15.51 & 11 & 60 & 58 \\
\hline Diarrhea >I month & 9.77 & 23 & 23 & 22 \\
\hline Pain abdomen & - & 9 & 6.6 & 20 \\
\hline Alteredsensorium & - & - & 26 & 4 \\
\hline Dysphagia & - & - & 30 & 4 \\
\hline
\end{tabular}

5. Clinical findings in general examination:The present study showed that skin lesions were present in $12 \%$ of patients, oral candidiasis in $26 \%$, significant lymphadenopathy in $40 \%$ and genital ulcer in $2 \%$ of cases. Much lower incidence were reported in studies by Colebunders $\mathrm{R}$ et al ${ }^{9}$, who 
reported skin lesions in $4.02 \%$, oral candidiasis in $9.77 \%$, lymphadenopathy in $7.47 \%$ and genital ulcer in $2.87 \%$. Lakshmi $\mathrm{V}$ et al ${ }^{10}$ reported oral candidiasis in $6 \%$, lymphadenopathy in $6 \%$ and genital ulcer in $5 \%$ of cases. However Kothari $\mathrm{K}$ et al ${ }^{5}$ reported a much higher incidence of skin lesions in $33 \%$, oral candidiasis in $70 \%$, lymphadenopathy in $43 \%$ and genital ulcers in $23 \%$ of patients.

The table showing comparable studies is given below.

\begin{tabular}{|c|c|c|c|c|}
\hline Study Series & $\begin{array}{c}\text { Skin Lesions } \\
\%\end{array}$ & $\begin{array}{c}\text { Oral candidiasis } \\
\%\end{array}$ & $\begin{array}{c}\text { Lymphadenopathy } \\
\%\end{array}$ & $\begin{array}{c}\text { Genital } \\
\text { Ulcer\% }\end{array}$ \\
\hline $\begin{array}{c}\text { Colebunders R } \\
\text { et al }{ }^{9}(1987)\end{array}$ & 4.02 & 9.77 & 7.47 & 2.87 \\
\hline $\begin{array}{c}\text { Lakshmi V } \\
\text { et al }{ }^{10}(1998)\end{array}$ & - & 6 & 6 & 5 \\
\hline \begin{tabular}{c}
$\mathrm{Kothari} \mathrm{K}_{\text {et al }}^{5}(2001)$ \\
\hline Present study
\end{tabular} & 33 & 70 & 43 & 23 \\
\hline
\end{tabular}

\section{Opportunistic infections and other associated conditions in HIV infected cases:}

a. Tuberculosis:In the present study most common opportunistic infection was tuberculosis with an incidence of $68 \%$. $38.23 \%$ had only pulmonary tuberculosis, $38.23 \%$ had only extrapulmonary tuberculosis and $23.54 \%$ had both pulmonary and extra pulmonary tuberculosis. However much higher incidence of pulmonary tuberculosis and lower incidence of extra pulmonary tuberculosis was shown by other studies done byHira S.K et al ${ }^{11}$ who reported 65.34\%pulmonary, $27.84 \%$ extra pulmonary and $6.82 \%$ both pulmonary and extra pulmonary tuberculosis. Rajasekaran S et al ${ }^{8}$ showed $55.6 \%$ of pulmonary tuberculosis and $30.5 \%$ combined disease. Zuber Ahmed et al ${ }^{12}$ showed $74.7 \%$ pulmonary tuberculosis, 19.8\% extra pulmonary tuberculosis and 5.5\% combined disease. However Chacko $S$ et al ${ }^{13}$ reported a lower incidence of pulmonary tuberculosis of $30 \%$ and higher incidence of combined disease with $48 \%$ and extra pulmonary tuberculosis constituting $22 \%$, when compared to above mentioned studies.

The comparable studies are given below:

\begin{tabular}{|c|c|c|c|c|c|}
\hline Tuberculosis & $\begin{array}{c}\text { Chacko } \\
\text { S et al }^{\mathbf{1 3}} \\
\mathbf{( 1 9 9 5 )} \\
\text { \% }\end{array}$ & $\begin{array}{c}\text { Hira } \\
\mathbf{S . K}^{\mathbf{1 1}} \text { et } \\
\text { al(1998) } \\
\mathbf{\%}\end{array}$ & $\begin{array}{c}\text { Rajasekaran } \\
\mathbf{S}^{\mathbf{8}} \text { et al } \\
\mathbf{( 2 0 0 0 ) \%}\end{array}$ & $\begin{array}{c}\text { Zuber } \\
\text { Ahmed } \\
\text { et al }^{\mathbf{1 2}} \\
\mathbf{( 2 0 0 3 )}_{\mathbf{\%}}\end{array}$ & $\begin{array}{c}\text { Present } \\
\text { Study }\end{array}$ \\
\hline Pulmonary & 30 & 65.34 & 55.6 & 74.7 & 38.23 \\
\hline Extra pulmonary & 22 & 27.84 & 13.9 & 19.8 & 38.23 \\
\hline Combined* & 48 & 6.82 & 30.5 & 5.5 & 23.54 \\
\hline
\end{tabular}

* Both pulmonary and extrapulmonary

Chest X-ray Findings and HIV infection:In the present study, 28 patients showed radiological abnormalities with upper zone lesions in $17.8 \%$, B/L infiltrations in $46.42 \%$, lower zone lesions in $10.71 \%$, pleural effusion in $10.71 \%$, pneumothorax in $3.57 \%$, miliary shadow in $7.14 \%$ 
andcardiomegalyin $3.57 \%$. These findings were comparable with other studies done by Chacko S et al ${ }^{13}$ who reported upperzone lesions in $26.92 \%$, B/L infiltrations in $23.07 \%$, lowerzone lesions in $7.69 \%$, pleural effusion in $15.38 \%$, pneumothoraxin $3.84 \%$, military shadows in $3.84 \%$ and hilar adenopathy in $19.23 \%$.

Arora et al $^{14}$ reported upper zone lesions in $17.65 \%$, B/L infiltrations in $29.42 \%$, lower zone lesions $11.75 \%$, pleural effusion in $17.65 \%$, military shadows in $5.89 \%$ and hilar adenopathy in $17.65 \%$.

However Agarwal et al ${ }^{15}$ reported a higher incidence of typical upper zone lesions in 57.1\%, $\mathrm{B} / \mathrm{L}$ infiltrations in $28.5 \%$ and lower zone lesions in $14.3 \%$ ofcases.

A table showing comparable study is given below:

\begin{tabular}{|c|c|c|c|c|}
\hline $\begin{array}{c}\text { Radiological } \\
\text { lesions }\end{array}$ & $\begin{array}{c}\text { Arora } \\
\text { et al } \mathbf{1 4} \\
\mathbf{( 1 9 9 3 )} \text { \% }\end{array}$ & $\begin{array}{c}\text { ChackoS } \\
\text { et al13 }\end{array}$ & $\begin{array}{c}\text { Aggarwal S.K } \\
\text { et al } \mathbf{1 5} \\
\mathbf{( 2 0 0 3 )}\end{array}$ & $\begin{array}{c}\text { Present } \\
\text { Study }\end{array}$ \\
\hline $\begin{array}{c}\text { Upper zone } \\
\text { lesions }\end{array}$ & 17.65 & 26.92 & 57.1 & 17.8 \\
\hline $\begin{array}{c}\text { B/L } \\
\text { infiltrations }\end{array}$ & 29.41 & 23.07 & 28.5 & 46.42 \\
\hline $\begin{array}{c}\text { Lower zone } \\
\text { lesions }\end{array}$ & 11.75 & 7.69 & 14.3 & 10.71 \\
\hline $\begin{array}{c}\text { Pleural } \\
\text { effusion }\end{array}$ & 17.65 & 15.38 & - & 10.71 \\
\hline Pneumothorax & - & 3.84 & - & 7.14 \\
\hline $\begin{array}{c}\text { Military } \\
\text { shadows }\end{array}$ & 5.89 & 3.84 & - & Cardiomegaly \\
\hline & $\begin{array}{c}\text { B/L hilar } \\
\text { adenopathy } \\
17.65\end{array}$ & $\begin{array}{c}\text { B/L hilar } \\
\text { adenopathy } \\
19.23\end{array}$ & - & 3.57 \\
\hline
\end{tabular}

Neurological manifestations in HIV disease:In the present study, 28\% of patients had neurological complications. Of these, $50 \%$ of patients had meningitis with all the cases being tubercular meningitis. We did not have any patients with cryptococcal meningitis. However studies done by Lakshmi et al ${ }^{10}$ reported meningitis in $70.59 \%$ of cases with $76.16 \%$ of them being tubercular, cryptococcal meningitis in $12.5 \%$ of cases and syphilitic meningitis in $8.33 \%$ of cases.

Sircar AR et al ${ }^{16}$ reported meningitis in $58.33 \%$ of cases with tubercular meningitis in $42.86 \%$ of cases and cryptococcal meningitis in $57.14 \%$.

Wadia R.S et al ${ }^{17}$ reported meningitis in only $17.88 \%$ of cases with majority of them being cryptococcal in etiology constituting $67.44 \%$ of the total meningitis cases. Tubercular meningitis was seen in $18.6 \%$, aspetic meningitis in $4.65 \%$, pyogenic meningitis in $5.81 \%$, syphilitic in $2.32 \%$ and both cryptococcal and tubercular meningitis in $1.16 \%$.

The above two mentioned studies reported much higher incidence of cryptococcal meningitis when compared to the present study. This could be explained by very large sample size in those studies. 
The present study showed tuberculoma in $14.28 \%$ of cases, spinal cord involvement in the form of myelo radiculopathy in 14.28\%, AIDS dementia complex in $7.14 \%$ and progressive multifocalleuco encephalopathy in $14.28 \%$.

However the other studies had not reported any cases of progressive multifocalleuco encephalopathy or muscular dystrophies or myopathies.

Lakshmi et al ${ }^{10}$ had reported tuberculoma in $5.88 \%$ of cases, myelo radiculopathy in $5.88 \%$ of cases and toxoplasma infection in $17.65 \%$ in contrast to the present study where we did not find toxoplasma infection affecting central nervous system in any case.

Sircar AR et al ${ }^{16}$ reported AIDS Dementia complex in $16.67 \%$ of cases and sensori motor neuropathy in $25 \%$ of cases.

Wadia RS et $\mathrm{al}^{17}$ reported myelopathy in $4.36 \%$ of cases, ADC in $4.36 \%$, neuropathies in $28.27 \%$ of cases and cranial neuropathies, seizures-, headache strokes, altered sensorium, meningism constituted $45.13 \%$ of cases.

However present study did not report any neuropathies in comparison to the above two studies.

The table showing the comparable studies is given below:

\begin{tabular}{|l|c|c|c|c|}
\hline & $\begin{array}{c}\text { Lakshmi } \\
\text { et al10 (1998) }\end{array}$ & $\begin{array}{c}\text { SircarA R } \\
\text { et al16 (1998) }\end{array}$ & $\begin{array}{c}\text { Wadia R.S } \\
\text { et al17 (2001) }\end{array}$ & $\begin{array}{c}\text { Present } \\
\text { Study }\end{array}$ \\
\hline Meningitis & 70.59 & 58.33 & 17.88 & 50 \\
\hline a. Tubercular & 79.16 & 42.86 & 18.6 & 100 \\
b. Cryptococcal & 12.5 & 57.14 & 67.44 & - \\
c. Aseptic & - & - & 4.65 & - \\
d. Pyogenic & - & - & 5.81 & - \\
e. Syphilitic & 8.33 & - & 2.32 & - \\
f. Combined & - & - & 1.16 & - \\
\hline Tuberculoma & 5.88 & - & - & 14.28 \\
\hline Myelopathy/Myeloradiculopath & 5.88 & - & 4.36 & 14.28 \\
y & - & 16.67 & - & 7.14 \\
\hline AIDS DementiaComplex & - & - & - & 14.28 \\
\hline Progressive Multifocal & & & & \\
Leucoencephalopathy & Toxoplasma- & Neuropathy & Neuropathy- & \\
\hline & 17.65 & $-25 \%$ & $29.27 \%$ & - \\
Any other & & Others -45.13 & \\
\hline
\end{tabular}

Sexually transmitted diseases (STD) and HIV: The present study reported one patient having Hepatitis B and one patient with genital gonorrhea constituting $2 \%$ each of total cases. This finding is comparable with study done byLakshmiet al ${ }^{10}$ which reported Hepatitis B in $2.3 \%$ of cases and Syphilis in $0.5 \%$ of cases. However much higher incidence of STDs was reported by Shah $\mathrm{H}$ et al ${ }^{18}$ who showed presence of syphilis in $10 \%$ of cases, Chancroid in $10 \%$, Herpes genitalis in $15 \%$, Condylomaaccuminata in $10 \%$, balonoposthitis in $30 \%$, Candidialvaginitis in $15 \%$ and nonspecific urethritis in $10 \%$ of cases. 


\section{ORIGINAL ARTICLE}

Sayal SK et al ${ }^{19}$ reported chancroid in $32.5 \%$, syphilis in $23 \%$, LGV in $11.9 \%$, gonorrhea in $2.6 \%$ and herpes genitalis in $3.2 \%$ cases.

This higher incidence of STD could be explained because their study was conducted in patients attending STD clinics.

Secondary bacterial infections and HIV: In the present study, out of 50 cases, 2 cases had pneumonia caused by gram negative bacilli and 1 patient had chronic suppurative otitis media.

However in a study done by Kothari $\mathrm{K}$ et $\mathrm{al}^{5}$ reported secondary infections in 7 patients (7/30) out of which 3 had pneumonia, 2 had lung abscess, 1 case had pyogenic meningitis and 1 had acute suppurative otitis media. Chacko $\mathrm{S}$ et al ${ }^{13}$ reported 18 cases of secondary infection with 11cases of pneumonia, 3 had urinary tract infection, 2 had enteric fever, 1 borderline lepromatous leprosy and 1 had gastroenteritis due to ShigellaSonnei.

The present study reported lesser incidence of secondary bacterial infections when compared to the above mentioned studies.

PersistentGeneralised Lymphadenopathy (PGL):The present study reported PGL in 2\% of cases which was much lowerwhen compared to studies done by Kothari Ket al ${ }^{5}$ who reported PGL in $20 \%$ of cases andSircar ${ }^{16}$ et al in $22.5 \%$ of cases.

Renal involvement and HIV:The present study reported 1 (2\%) case of chronic renal failure and 1 (2\%) case of HIV associated nephropathy. This finding is comparable with the study done by Kothari Ket $\mathrm{al}^{5}$ who reported HIV associated nephropathy in 3.3\% of cases and renal involvement in the form of albuminuria and hematuria in $7 \%$ of cases.

Malignancies and HIV:The present studyreported 1 case of Non-Hodgkin's lymphoma and 1 case of suspected Kaposi's sarcoma which is comparable with other studies done by Kothari $\mathrm{K}^{5}$ et al who reported 1 case of Non-Hodgkin's lymphoma.

Chacko Set al ${ }^{13}$ reported 1 case of Non-Hodgkin's lymphoma and 2 suspected lymphomas where definitive diagnosis could not be done because of lack of facilities.

In many resource poor countries, clinicians are severely limited in the useofstandard of care assays to help determine disease progression in HIV positivepatients. This limitation can result in a potentially dangerous postponement of theinitiation of antiretroviral therapy ${ }^{19-26}$ Previous studies had shown that TLC is a low cost and useful tool for monitoring HIV progression and triggering Opportunistic infection prophylaxis in resource poor settings.

In this setting WHO recommends using the total lymphocyte count (TLC) as a surrogate marker for the CD4 T cell count. If the CD4 lymphocyte count is not available, WHO recommends initiating HAART in WHO stage II andIII disease when accompanied by a TLC of less than 1200 cells $/ \mathrm{mm}^{3}$.

Depletion of CD4+ T cells is one of the hallmarks of progression of HIV-1infection and CD4 count has been established to be a standard laboratory marker of disease progression in HIV3, ${ }^{24}$.Howeverin many resource limited countries, the cost of CD4 count are so high relative to reduced prices of antiretroviral drugs, thatroutine monitoring of therapy would often be more expensive than the supply of drugs themselves. Also unavailability of sophisticated laboratory 
equipment to measure CD4+ count preludes their use in large parts of the world. Previous studies had suggested that the total lymphocyte count (TLC) can beused to predict a low absolute CD4+ T cell. 3, 27-30,

According to WHO recommendation, when CD4 testing is unavailable, then patient can be started on HAART therapy, if patient has

WHO stage IV disease irrespective of total lymphocyte count.

$>$ WHO stage II or III disease with total lymphocyte count 1200 cells $/ \mathrm{mm}^{3}$.

Treatment is also recommended for patients with advanced WHO stage II disease including recurrent or persistent oral thrush and recurrent invasive bacterialinfections irrespective of CD4 count or TLC.

We undertook to look at the correlation between the CD4 count and TLC inHIV patients with advanced disease. CD4 counts of 200 orless were correlated with total lymphocyte count of 1200 or less.

It was also noted that patients had a mean CD4 count of 175 cells $/ \mathrm{mm}^{3}$ andpatients had a mean TLC of 1338 cells/mm3. These observations were comparable with other study groups.

On calculating linear correlation between CD4 count of $<200$ cells $/ \mathrm{mm}^{3}$ and TLC of $<1200$, there was high statistical significance with sensitivity of $91 \%$, specificity of $53 \%$ and positive predictive value of $70 \%$.

The scatter diagram shows that as the CD4 count level increases the TLC level also increases and there was a significant correlation between CD4 and TLC.

The values of our study were correlated with other national and international studies

\begin{tabular}{|c|c|c|c|c|c|c|}
\hline Place & $\begin{array}{l}\text { NO. of } \\
\text { pts. }\end{array}$ & Aim & Sensitivity & Specificity & $\begin{array}{c}\text { TLC for } \\
\text { CD4 }<200 \\
\text { cells } / \mathbf{m m}^{3}\end{array}$ & Results \\
\hline \multirow[t]{2}{*}{$\begin{array}{l}\text { John Hopkins } \\
\text { University }\end{array}$} & \multirow{2}{*}{1451} & \multirow[t]{2}{*}{$\begin{array}{l}\text { Correlation TLC } \\
\& \mathrm{Hb} \% \text { to predict } \\
\mathrm{CD} 4<200 \text { before } \\
\text { initiation of } \\
\text { HAART }\end{array}$} & $78 \%$ & $37.3 \%$ & $<1200$ & $\begin{array}{l}\text { TLC } \quad<1200 \\
\text { cells } / \mathrm{mm}^{3} \\
\text { significantly } \\
\text { predict CD4 } \\
\text { count }<200\end{array}$ \\
\hline & & & $70.7 \%$ & $81.8 \%$ & $<1200$ & $\begin{array}{l}\text { TLCC }<1200 \\
\text { cells } / \mathrm{mm}^{3} \\
\text { significantly } \\
\text { predict CD4 } \\
\text { count }<200\end{array}$ \\
\hline \multirow{2}{*}{$\begin{array}{l}\text { YRG Centre } \\
\text { for AIDS } \\
\text { research and } \\
\text { education } \\
\text { Chennai, India }\end{array}$} & \multirow[b]{2}{*}{650} & \multirow{2}{*}{$\begin{array}{l}\text { To evaluatethe } \\
\text { correlation of } \\
\text { TLC to CD } \\
\text { count }\end{array}$} & $73 \%$ & $50 \%$ & $<1400$ & $\begin{array}{l}\text { Correlated } \\
\text { with CD4 }<200 \\
\text { cell } / \mathrm{mm}^{3}\end{array}$ \\
\hline & & & $70 \%$ & $86 \%$ & $\begin{array}{l}\text { TLC } \\
<1700 / \\
\text { CD4<350 }\end{array}$ & $\begin{array}{l}\text { Significant } \\
\text { correlation } \\
\text { b/w } \mathrm{TLC}<1700 \\
\text { and CD4 }<350 \\
\text { cells } / \mathrm{mm}^{3}\end{array}$ \\
\hline
\end{tabular}




\begin{tabular}{|l|l|l|l|l|l|l|}
\hline $\begin{array}{l}\text { YMCH, } \\
\text { Mangalore }\end{array}$ & \multirow{2}{*}{50} & $\begin{array}{l}\text { To correlate b/w } \\
\text { CD4 count \& TLC }\end{array}$ & & & $\begin{array}{l}\text { TLC of } \\
1200 \text { or }\end{array}$ & $\begin{array}{l}\text { Significant } \\
\text { correlation } \\
\text { b/w CD4 }\end{array}$ \\
& & $91 \%$ & $53 \%$ & $\begin{array}{l}\text { less } \\
\text { correlate } \\
\text { with CD4 } \\
\text { count 200 }\end{array}$ & \\
\hline
\end{tabular}

Apart from the studies mentioned above, R Wood, F Post and G Maartene, (Cape Town, South Africa)..$^{30}$ also studied CD4 and total lymphocyte counts as predictors of HIV disease progression and concluded that for each clinical stage, a significant difference in progression to AIDS and mortality was predicted by TLC above or below 1250 cells $/ \mathrm{mm} 3$. Survival and progression to AIDS occurred at similar rates in patients with TLC 1250 cells $/ \mathrm{mm} 3$ or CD 4 count of $200 \mathrm{cells} / \mathrm{mm}^{3}$.

Another study done by Beck EJ et al ${ }^{32}$, at Academic Department of Public Health, St Mary's Hospital Medical School, London, UK on 1534 paired Total Lymphocyte count and CD4 count, a significant correlation did exist and the high correlation between total and CD4 lymphocyte counts, especially for patients with symptomatic HIV disease, demonstrated the suitability of the use of TLC in the absence of CD 4 counts. Given the considerably lower prices of TLCs compared with $\mathrm{T}$ - cell subset analysis, this is particularly relevant for developing countries.

To summarize, a total of 15, 102 patients enrolled in 15 different studies were followed up to determine the ability of the total lymphocyte count to predict the CD4 cell count and HIV disease stage ${ }^{33}$. Eleven of these studies (which induced a total of 11, 713 patients) contained data that, overall, indicated support for the predictive ability of the total lymphocyte count, whereas four had concluded that TLC was not a reliable predictor of the CD4 cell count 33 .

Studies done in John Hopkins University Bloomberg School of Public Health analyzed stated that a TLC decline of greater than $10 \%$ per year and Hemoglobin decline of greater than $22 \%$ per year was noted in over $77 \%$ of study participants whodeveloped AIDS 34,20

The pattern of CD4+ counts over time is more important than any single CD4+ count value. CD4+ counts generally decrease as HIV progresses. Therefore it is more valuable to evaluate a series of CD4+ counts than any single count. ${ }^{20}$

As the CD4 count is affected by the time of the day (lower in the morning), in acute illness, refrigeration of blood sample (decrease CD4+ counts) or with rough handling or contamination of blood sample, serial recording of TLC and hemoglobin can give an equally stable reflection of progression of disease and development of AIDS in HIV positive patients. ${ }^{33}$

It becomes more feasible especially in developing countries as a CD4 count costs around \$ 30 US while TLC costs around 0.80 US \$35, monitoring the patient with TLC will have an enormous cost benefit in patients with limited resources.

Limitations of this study necessitate further investigations. As this was an observational study of subjects in Mangalore, more assessment of TLC using data from the target countries are needed. Conditions specific to resource limited settings, such as the higher prevalence of leukocytosis due to inter current infections, may influence the interpretability of changes in TLC. Further, as has been shown with CD4 count, TLC values as well as the dynamics of the measure may vary across different ethnicities. Region-specific validation of CD4 and TLC changes on HAART are needed. Also, TLC measured by complete blood count may not be possible in very low income 


\section{ORIGINAL ARTICLE}

countries or remote regions. Therefore, the evaluation of TLC measured by light microscopy and manual cell counting may be beneficial.

\section{CONCLUSION:}

- In this study we conclude that most of the clinical observations were in accordance with the other studies conducted earlier. The study showed male preponderance with heterosexual mode of transmission being the commonest mode of transmission. Fever, weight loss and diarrhea continue to be the presenting symptoms. Tuberculosis was the most common opportunistic infection. Among various neurological manifestations, tubercular meningitis was the commonest and unlike in other studies, there was absence of cyptococcal meningitis and toxoplasmosis in our study.

- Thus HIV infection can present with varied manifestations depending on geographic, socioeconomic and cultural environment and thus needs a high index of suspicion for early detection of case and management.

- Our study shows a definite correlation between TLC and CD4 count in HIV positive patients. CD4 counts of less than 200 cells/mm3 showed a statistically significant correlation with TLC of less than 1200 cells $/ \mathrm{mm} 3$

- TLC can be substituted for the CD4 count when the latter is unavailable and HIV related symptoms exist.

- TLC could be used as a low cost tool and as a surrogate marker for monitoring HIV disease and its progression.

- These results could be very useful for regions with scarce health care resources as an alternative way of identifying individuals who should receive HAART therapy for HIV infection. We believe further research in appropriate population is warranted.

- For the people who may not be able to afford the treatment and may get free supply of antiretroviral medicine, TLC can serve as a cost effective, affordable index to start HAART treatment and also to monitor HAART treatment.

\section{BIBLIOGRAPHY:}

1. Global programme on AIDS July 3, 1995. The current global situation of HIV-AIDS pandemic, Geneva: World Health Organization.

2. Dowbenko D, Nakamura G, Fennie C, et al. Epitope mapping of the human immunodeficiency virus type 1 gp120 with monoclonal antibodies. J Virol. 1988 Dec; 62(12):4703-11.

3. Kumarasamy N, Mahajan AP, Flanigan TP, et al. Total lymphocyte count (TLC) is a useful tool for the timing of opportunistic infection prophylaxis in India and other resource-constrained countries. J Acquir Immune DeficSyndr. 2002 Dec 1; 31(4):378-83.

4. Kothari K., Goyal S; Study of clinical presentation, spectrum of systemic involvement and opportunistic infections in AIDS patients Journal of Association of Physicians of India. 2001; 49:435-438.

5. Ghate M.V., Divekar A.D, Risbud AR. Changing Trends in clinical presentation in referred Human immunodeficiency virus infected persons in Pune, Indian Journal of Association of Physicians of India 2002; 50: 671- 673. 


\section{ORIGINAL ARTICLE}

6. Mandal AK, Singh V. P., Gulati AK. Prevalence of Human Immuno deficiency virus infection in and around Varanasi, Uttar Pradesh. Indian Journal of Association of Physicians of India. 2000; 48 (3) 288 - 289.

7. John T.J, Babu P.G, Saraswathi N.K, The epidemiology of AIDS in the Vellore region southern India. Journal of Acquired Immuno deficiency syndrome, 1993; 7(3): 421-424.

8. Rajasekaran S., Uma A, Kamakshi. Trend of HIV infection inpatientswith tuberculosis in rural south India. Ind. J. Tub, 2000; 47: 223-226.

9. Colebunders Robert, Mann JM, Henry Francis, KapitaBila, LebugheIzaley, Ndangikakonde et al. Evaluation of clinical case Definition of Acquired immunodeficiency syndrome in Africa. Lancet. 1987; $492-494$.

10. . Lakshmi V, Teja V.D., Sudha Rani T. Human immuno deficiency virus infection in a Tertiary care Hospital - Clinical and microbiological profile. Journal of Association of Physicians of India. 1998; 46; 363 - 367.

11. Hira S.K, Dupont H.L, Lanjewar D.N. Severe weight loss; the predominant clinical presentation of tuberculosis in patients with HIV infection in India. Natl. Med India; 1998; 11: 256- 258.

12. Ahmed Zuber, Bhargava Rakesh, Pandey D.K. HIV infection seroprevalence in tuberculosis patients. Ind. J. Tub, 2003; 50: 151-154.

13. Chacko S, John TJ, Babu PG, Jacob M, Kaur A, Mathai D. Clinical profile of AIDS in India; a review of 61 cases. J Assoc Physicians India; 1995; 43:535-8.

14. Arora VK, Seetharam ML, Gowrinath K, Lung and HIV infection with special reference to tuberculosis; Preliminary report on 20 HIV - 1 seropositive cases. Ind J. Chest Dis AlliSci 1993; 35: $103-112$.

15. Agarwal SK, MakhijaAman, Singh N.P. Tuberculosis in HIV/ AIDS patients in a tertiary care hospital in Delhi. Ind. J. Tub, 2003 50; 163 - 165.

16. Sircar AR, Tripathi AK, Choudhary S.K, Misra R. Clinical profile of AIDS; a study at a tertiary hospital. Journal of Association of Physicians of India 1998; 46: 775 - 778.

17. Wadia R.S, Bijari S.N, Kothari S, Neurological manifestations ofHIV disease. Journal of Association of Physicians of India 2001; 49; 343 - 348.

18. Shah H, Lakshmi J, Trivedi S. Cutaneous manifestations in HIVinfected cases in rural hospital of Gujarat. Indian J Sex Transco Dis, 1998; 19: 95-97.

19. Sayal S.K. Gupta C.M., Sangli S, HIV infection in patients of sexually transmitted disease. Ind J. DermatolVenereal Leprol, 1999; 55: 131-133.

20. Rapid declines in total lymphocyte counts and hemoglobin concentration prior to AIDS among HIV-1 infected men, appear in the official journal of the international AIDS Society Sept. 2003 issue of AIDS.

21. World Health Organization Scaling up antiretroviral therapy in resource limited settings guidelines for a public health approach Geneva WHO April 2002.

22. Evan der Ryst et al Correlation among total lymphocyte count absolute CD4 count and percentage in a group of HIV-1 infected South African Patients. Journal of Acquired Immune Deficiency syndromes and Human Retrovirology 19 238-244; 1998.

23. FA Post and others. CD4 total lymphocyte counts as predictors of HIV disease progression. Quarterly Journal of Medicine 89; 505-508; 1996. 


\section{ORIGINAL ARTICLE}

24. SJ Gange et al Use of total lymphocyte count and hemoglobin for staging HIV disease and possibly initiating antiretroviral therapy. In XIVth International AIDS Conference Barcelona, Spain, July 2002 (Abstract TuPe C4706).

25. T. Flanigan and others. Total lymphocyte count as a surrogate for CD4 count to initiate and monitor HAART in resource-limited countries. In 9th Conference on Retroviruses and Opportunistic Infections Seattle Washington February 2001.

26. LA Spacek and others. Total lymphocyte count and hemoglobin combined in an algorithm to initiate the use of highly active antiretroviral therapy in resource limited AIDS June 13, 2003; 17(9) 1311-1317.

27. Costello, Karoloine, Nelson, Denise J MD et.al.- predictors of low CD4 count in resource limited setting: based on an antiretroviral naive heterosexual Thai population. JAIDS Journ of acquired immune deficiency syndromes June 1" 200539(2); 242-248

28. Flanigan T, Kumaraswamy, S Solomon et. Al. TlyC as a surrogate for CD4 count to initiate and monitor HAART in resource limited countries. 9th conference on retroviruses and opportunistic infections, wattle, Washington, Feb 24-28 2002.

29. Schreibman T, Friedland G- use of Tlyc for monitoring response to ARV therapy, clip infect dis. 2004 Jan 15; 38(2); 257-62

30. Mwanbury DM, Ghosh M, Gorbsach SL, predicting CD4 count using TlyC: a sustainable tool for clinical decisions during HAART use. Am J Trop Hyg. 2005 July 73(1); 58-62

31. Badri. M Wood r., Usefulness of total lymphocyte count in monitoring highly active antiretroviral therapy in resource-limited settings. Somerset Hospital University of Cape Town, South Africa, AIDS 2003; Mar 7; 17 (4); 541-5

32. Beck EJ., Kupek EJ., Gompels MM, Pinching AJ, Correlation between total and CD4 lymphocyte counts in HIV infection not making the good an enemy of the not so perfect. Academic department of public health. St. Mary's Hospital Medical School, London U.K. Int J STD AIDS, 1996 Oct 7(6) 422-8.

33. HIV Treatment Bulletin Volume 5 November 1 /2 February / March 2004.

34. AIDS development can be monitored and predicted Joint Hopkins University Bloomeberg School of Public Health 10 Sept 2003 Ohuph.edu).

35. Mahajan AP., Hogan JW., Snyder B., Kumarsamy N, Mehta K., Solomon s. Carpenter CC., Mayer $\mathrm{KH}$., Flanigan TP. Changes total lymphocyte count as a surrogate for changes in CD4 count following initiation of HAART implications for monitoring in resource-limited settings. Acquir immune DeficSyndr 2004 Apr 20; 36 (1); 567-575. 


\section{ORIGINAL ARTICLE}

\section{AUTHORS:}

1. SajidChalihadan

2. Mohammed Kunhi

3. C.P. Abdul Rahman

\section{PARTICULARS OF CONTRIBUTORS:}

1. Assistant Professor, Department of Medicine, Yenepoya Medical College, Nithyanandanagar, Deralakatte, Mangalore, Karnataka.

2. Professor, Department of Medicine, Yenepoya Medical College, Nithyanandanagar, Deralakatte, Mangalore, Karnataka.

3. Professor, Department of Medicine, Yenepoya Medical College, Nithyanandanagar, Deralakatte, Mangalore, Karnataka.

\section{NAME ADDRESS EMAIL ID OF THE CORRESPONDING AUTHOR:}

Dr. Sajid Chalihadan., BMK Villa, Vaslane, Near Unity Hospital, Balmatta Post, Mangalore - 575002 .

Email-drchsajidmd@yahoo.co.in

Date of Submission: 16/12/2013. Date of Peer Review: 17/12/2013. Date of Acceptance: 24/12/2013. Date of Publishing: 26/12/2013. 